\title{
Entrepreneurship Education and Venture Intention of Female Engineering Students in A Nigerian University
}

\author{
Fred Peter ${ }^{1}$, Sunday Eze ${ }^{1}$, Kelechi Osigwe $^{1}$, Mercy Adeyeye ${ }^{1}$, Adeshola Peter ${ }^{1}$, Emmanuel Adeyemi $^{1}$, Chibogu \\ Okolugbo $^{2} \&$ Temitope Asiyanbola ${ }^{1}$ \\ ${ }^{1}$ Landmark University, Omu-aran, Kwara State, Nigeria \\ ${ }^{2}$ Ekiti State University, Ado-Ekiti, Ekiti State, Nigeria \\ Correspondence: Fred Peter, Landmark University, Omu-aran, Kwara State, Nigeria.
}

Received: August 18, 2020

Accepted: January 27, 2021

Online Published: January 29, 2021

doi:10.5430/ijhe.v10n4p9

URL: https://doi.org/10.5430/ijhe.v10n4p9

\begin{abstract}
The significant changes taking place in the world have offered new opportunities for male and female-owned businesses. This study investigated the impact of entrepreneurship education and venture intention of female engineering students in Nigeria. A descriptive research design was used. Copies of the questionnaire were distributed to collect quantitative data on the link between entrepreneurship education and venture intentions of Landmark university female engineering students. The sample size for this study was determined based on the entire population of 32. This study used purposive random sampling techniques for the selection of the respondent. Hence, each participant was given an equal chance of being chosen from the population in no particular order. Regression analysis was used to analyse the stated hypotheses through a statistical package for social science (SPSS). The findings revealed that effective implementation of entrepreneurship education elements stimulate students' entrepreneurial activities, particularly among female engineering students. This study advanced knowledge and concluded that entrepreneurship education elements such as pedagogy, educators' competence, and learning environment have a significant impact on venture intention.
\end{abstract}

Keywords: entrepreneurship, pedagogy, female entrepreneurship, venture intention, engineering, curriculum content

\section{Introduction}

The country's economic strength and prosperity is determined by the creativity and innovation of its people. While many institutions of higher learning are focusing their attention on training and producing a highly competent workforce, Universities with engineering departments are challenged to motivate their students to work hard towards identifying societal needs and transform their technical and entrepreneurial competencies into commercializeable products and services (Badri \& Hachicha, 2019). In line with this, engineering students participate in entrepreneurship programmes that expose them to business skills that inspire the expression of entrepreneurial potentials, critical thinking, and actions (Igwe et al., 2019). However, women participation in entrepreneurial activities is a growing phenomenon globally (Zahra \& Wright, 2016; Martinez Dy \& Marlow, 2018). It accounts for the creation of economic and social values such as job creation, growth, and women empowerment (McMullen \& Warnick, 2016). Despite its benefits, women participation in entrepreneurship is low in most developing countries due to the socio-cultural pressures (Jamali, 2009).

Nigeria has been plagued with rising graduate unemployment and underemployment among other social problems (Onuma, 2016). And most graduates are not equipped with basic entrepreneurial skills to venture into businesses. In response to this problem, education stakeholders enacted policies on education, revitalizing entrepreneurship education to address the nagging problem of graduate unemployment and made it compulsory for all tertiary institutions in Nigeria. The Federal Ministry of Education mandated a policy on the addition of entrepreneurship education in the curricula of tertiary institutions in the Nation. Entrepreneurship education has become imperative in institutions of higher learning in the Nation because it offers a genuine and practicable methodology to resolving the prevalent problem of joblessness (Gabadeen \& Raimi 2012; Jena, 2020). The overall aim of entrepreneurship education policy in Nigerian tertiary institutions is to nurture entrepreneurship culture among students and faculty for both educating and supporting the establishment of business ventures (Yahaya, 2011 cited in Gabadeen \& Raimi, 2012; Oguntimehin, 2018; Ogbari et al. 2018). 
Therefore, this suggests that entrepreneurship education in Nigerian tertiary institutions is introduced to empower students with entrepreneurial expertise that would motivate students to be job inventors and not job seekers. Despite this move, the craving for white-collar jobs has persisted. Similarly, the low participation of females in an engineering field, gender inequality, and family factors (marriage and child-rearing) are major factors that constituted a stumbling block to female entrepreneurship in the engineering field (Parker, 2018; Raimi et al, 2015). This study purposes to examine the impact of entrepreneurship education on venture intention female engineering students.

\section{Literature Review}

\section{Female Entrepreneurship}

Fostering female entrepreneurship has been recognized as one of the major ways to boost the level of entrepreneurship and achieve economic prosperity (Jena, 2020). The major motivation for focusing on female entrepreneurship is attributed to the increasing awareness of the vital role played in starting, running, and growing businesses that have a profound impact on economic growth. Existing literature indicates that the motivation to actively participate in entrepreneurial ventures is similar for male and female. Such motivation is encapsulated in the desire to be independent and a need for achievement (Buttner, 1993; Orhan \& Scott, 2001; Orhan 2001; Ahmed et al., 2020). Also, Gosselin and Grisé (1990) posit that the desire for independence is one of the main reasons cited by female entrepreneurs globally for launching their own business. However, Adeyeye (2017) highlighted the recognition of opportunity and the desire to invent, extend an existing product, adopting and adapting an existing concept and synthesis as the approach for venture intentions (market innovation). While the drive for entrepreneurship in some women is rooted in negative environments, others are motivated by positive opportunities (Goby \& Erogul, 2011). Education on entrepreneurship plays a key role in the development of an individual's skills and competencies (Dou et al., 2019). And it is recognized by scholars and policymakers globally (Almeida et al., 2019).

In this light, female entrepreneurs are a bundle of untapped resources that can be explored not only as a solution to the nagging problem of unemployment but also to leverage on their latent contribution to economic wealth and prosperity (Badri and Hachicha, 2019). In the Nigerian context, cultural limitations and traditional mindsets serve as bottlenecks to starting and running female-owned businesses. The emphasis put on cultural boundaries like the male/female role classifications that tag women as characteristically inferior to men, particularly in the rural context where female entrepreneurs are often not valued. Although, a number of women have very low appetite for risk and entrepreneurial pursuit because entrepreneurial activities are meant for men only, due to risks and demands associated with it (Mwobobia, 2012). According to Ibidunni et al. (2018), gender, age, and educational qualifications are determinants of entrepreneurship's ability to develop new products. Ismail et al., (2015) reveal that entrepreneurial intention and orientation have a key impact on the commercialization of research. However, the major problem confronting female entrepreneurs highlighted by (Ahmed et al.; Ahmad 2011) is the absence of networking between female entrepreneurs and other entrepreneurial associations that provide them access to business training and competences due to time constraint arising from family responsibilities, thus limiting female entrepreneurs for giving expression to their full potentials (Moses \& Amalu, 2010).

\section{Feminism Theory}

The liberal feminism theory as noted by DeMartino and Barbato, (2003) assumes that men and women should express their political, economic and social aspirations equally. Therefore, rationality and not sex should be used as a parameter for an individual right. Although the theory can be subclassified into various theories; liberal feminism theory, cultural feminism, social feminism theory, amazon feminism, and separatist's theories. This study focuses on liberal feminism theory because of several limitations confronted by female entrepreneurs within the Nigerian business environment.

The liberal feminism theory is rooted in the notion of equality, entitlement, and individual rights. It recognizes that in the context of entrepreneurship if women are exposed to the various opportunities such as education, business skills, work experience, and other resources available to men in the society, they will perform similarly (Unger \& Crawford, 1992). This gives us a compelling argument on the reasons why SME sub-sector in Nigerian are dominated by women who operate at subsistence level. 


\section{Methodology}

\section{Study Area}

Landmark University is a private Christian mission tertiary institution situated in Omu-Aran, Kwara State. It boasts of over 4000 students. Landmark University (LMU) offers courses and programs leading to officially recognized tertiary education degrees such as bachelor's degrees, master's degrees, and doctorate degrees in numerous areas of study.

The study adopts a descriptive approach so as to obtain students' opinion on the effect of entrepreneurship education on the venture intention of female engineering students in Nigeria. A descriptive research design was adopted because it captures relevant information regarding current practices on the subject matter. Quantitative data was collected on the link between entrepreneurship education and venture intentions of Landmark University female engineering students through the distribution of questionnaire. The authors choose to examine the whole population since the size has a homogenous set of features (female core engineering undergraduates) which is typically very small. The questionnaire was partitioned in two major sections; the first section captures the respondents' demographic characteristics; while the second section contains the measurement indices for the independent (entrepreneurship education), and dependent (venture intention) variables. A Likert- scale questions starting from strongly agree to strongly disagree was used (strongly agree $=5$, agree $=4$, undecided $=3$, disagree $=2$, strongly disagree-1).

Partial Least Squares Structural Equation Modelling PLS-SEM which is used for small sample size (less than 50) and non-normal data as proposed by Jannoo et al., (2014) was adopted for the analysis of data generated from the distributed questionnaire. Descriptive and inferential statistics were used to present the results of the study. A sample of 32 respondents was targeted from which all respondents filled in and reverted the questionnaires. This response rate was satisfactory to make conclusions for the study as it is a representation of the population. The study was conducted from 20/02/2018 to 15/07/2019.

\section{Operationalization of the Research Variables}

The impact of entrepreneurship education and venture intention of female engineering students is operationalized mathematically as follows:

$\mathrm{Y}=\mathrm{f}(\mathrm{X})$

Where $\mathrm{Y}$ is a dependent variable, $\mathrm{f}$ is a function and $\mathrm{X}$ is an independent variable

Therefore,

$\mathrm{Y}=$ Venture Intention $(\mathrm{VI})$

$\mathrm{X}=$ Entrepreneurship Education $(\mathrm{EE})$

$\mathrm{Y}=\mathrm{VI}=\left(\mathrm{y}_{1}, \mathrm{y}_{2}, \mathrm{y}_{3} \ldots \mathrm{y}_{\mathrm{n}}\right)$

$\mathrm{Y}_{1}=$ Critical Thinking

$\mathrm{Y}_{2}=$ Innovation

$\mathrm{Y}_{3}=$ Opportunity Identification

$\mathrm{X}=\mathrm{EE}=\left(\mathrm{x}_{1}, \mathrm{x}_{2}, \mathrm{x}_{3} \ldots \mathrm{x}_{\mathrm{n}}\right)$

$\mathrm{X}_{1}=$ University Learning Environment

$\mathrm{X}_{2}=$ Curriculum Content

$\mathrm{X}_{3}=$ Educator's Competence 


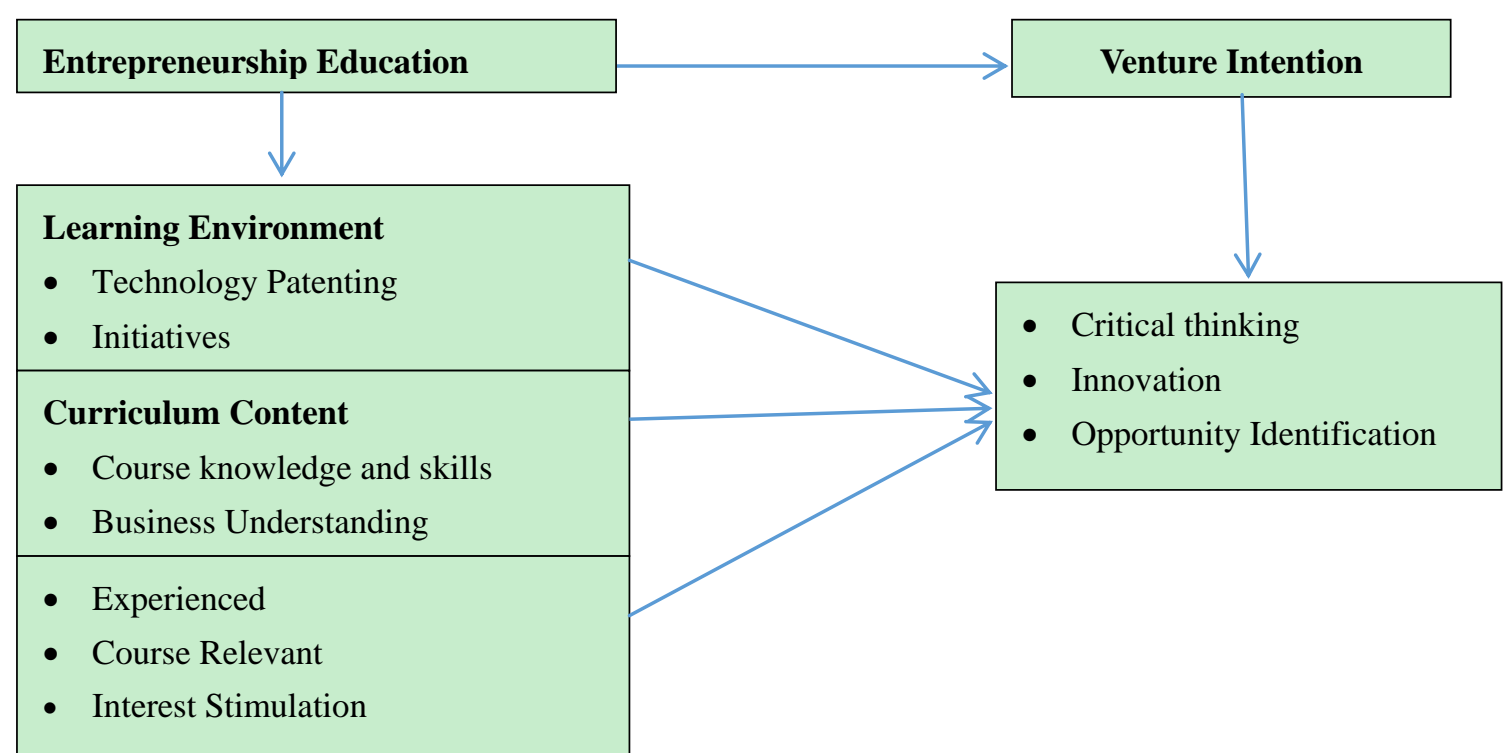

Figure 1.

Conceptual Framework

\section{Results}

Table 1. Demographic Information of respondents

\begin{tabular}{ccc}
\hline Category & Frequency & Percentage \\
\hline Departments & 3 & \\
Agric \& Biosystem & 8 & 9.4 \\
Chemical & 9 & 25 \\
Civil & 9 & 28.1 \\
Electrical \& Information & 3 & 28.1 \\
Mechanical & 32 & 9.4 \\
Total & 32 & 100.0 \\
\hline
\end{tabular}

As indicated in table 1 above, majority of the respondents as shown by $28.1 \%$ were in Civil engineering and Electrical and Information department, followed by Chemical, Mechanical and Agric and Biosystems accordingly. The result of the standard deviation and the Mean imply rational distribution.

Table 2. Entrepreneurship Course Development

\begin{tabular}{lrr}
\hline \multicolumn{1}{c}{ Statistics } & & \\
Curriculum Contents & Mean & Std. Deviation \\
\hline course develop entrepreneurial understanding & 3.78 & 1.039 \\
course develop entrepreneurial knowledge and skills & 3.81 & .965 \\
course raise entrepreneurship interest & 3.94 & 1.076 \\
Educator's Competence & & .897 \\
experience and competent instructors & 3.97 & .716 \\
relevant course & 4.06 & .647 \\
interest stimulation & 3.97 & \\
Learning environment & & 1.162 \\
promotion of technology patenting and commercialization & 3.44 & \\
\hline
\end{tabular}




\begin{tabular}{lll} 
entrepreneurship fostering & 3.38 & 1.100 \\
entrepreneurship seed funding & 3.22 & 1.128 \\
Critical thinking & & .897 \\
develop ideas on existing business problems & 3.97 & .740 \\
develop ideas to improve existing products & 3.97 & .793 \\
develop new product ideas & 4.13 & .801 \\
Opportunity Identification & & .861 \\
identify entrepreneurship needs & 3.94 & .859 \\
discover skills in business opportunities & 4.03 & \\
identify several businesses opportunities & 3.81 & 1.012 \\
Innovation & & 1.047 \\
develop new products & 3.59 & 1.051 \\
develop new technologies processes & 3.47 & 3.84 \\
develop new business processes & & \\
\hline
\end{tabular}

Table 2 , indicates that majority of the respondents agree that Landmark University entrepreneurship programmes provide courses that are consistent with the elements of the independent variable such as (Curriculum Contents), Educator's Competence and Learning environment) and elements of dependent variable (critical thinking, opportunity identification and innovation)

\section{Content Validity}

The content validity of the work is determined by deleting any items with a low factor loading less than 0.5 and retain the one above 0.5

Table 3. Content Validity

\begin{tabular}{|c|c|c|c|c|c|c|}
\hline $\begin{array}{c}\text { Item/ } \\
\text { Construct }\end{array}$ & $\begin{array}{c}\text { Critical } \\
\text { Thinking }\end{array}$ & $\begin{array}{c}\text { Curriculum } \\
\text { Content }\end{array}$ & $\begin{array}{l}\text { Educator's } \\
\text { Competence }\end{array}$ & Innovation & $\begin{array}{c}\text { Learning } \\
\text { Environment }\end{array}$ & $\begin{array}{l}\text { Opportunity } \\
\text { Identification }\end{array}$ \\
\hline CC1 & & 0.605 & & & & \\
\hline $\mathrm{CC} 2$ & & 0.846 & & & & \\
\hline $\mathrm{CC3}$ & & 0.769 & & & & \\
\hline CT1 & 0.913 & & & & & \\
\hline CT2 & 0.817 & & & & & \\
\hline CT3 & 0.654 & & & & & \\
\hline EC1 & & & 0.765 & & & \\
\hline EC2 & & & 0.833 & & & \\
\hline EC3 & & & 0.785 & & & \\
\hline INV1 & & & & 0.736 & & \\
\hline INV2 & & & & 0.874 & & \\
\hline INV3 & & & & 0.671 & & \\
\hline LE1 & & & & & 0.752 & \\
\hline LE2 & & & & & 0.902 & \\
\hline LE3 & & & & & 0.696 & \\
\hline OP1 & & & & & & 0.709 \\
\hline OP2 & & & & & & 0.827 \\
\hline OP3 & & & & & & 0.841 \\
\hline
\end{tabular}


CC: Curriculum Content; CT: Critical Thinking; EC: Educator's Competence; INV: Innovation; LE: Learning Environment; OP: Opportunity Identification

The Prediction Quality of the Model

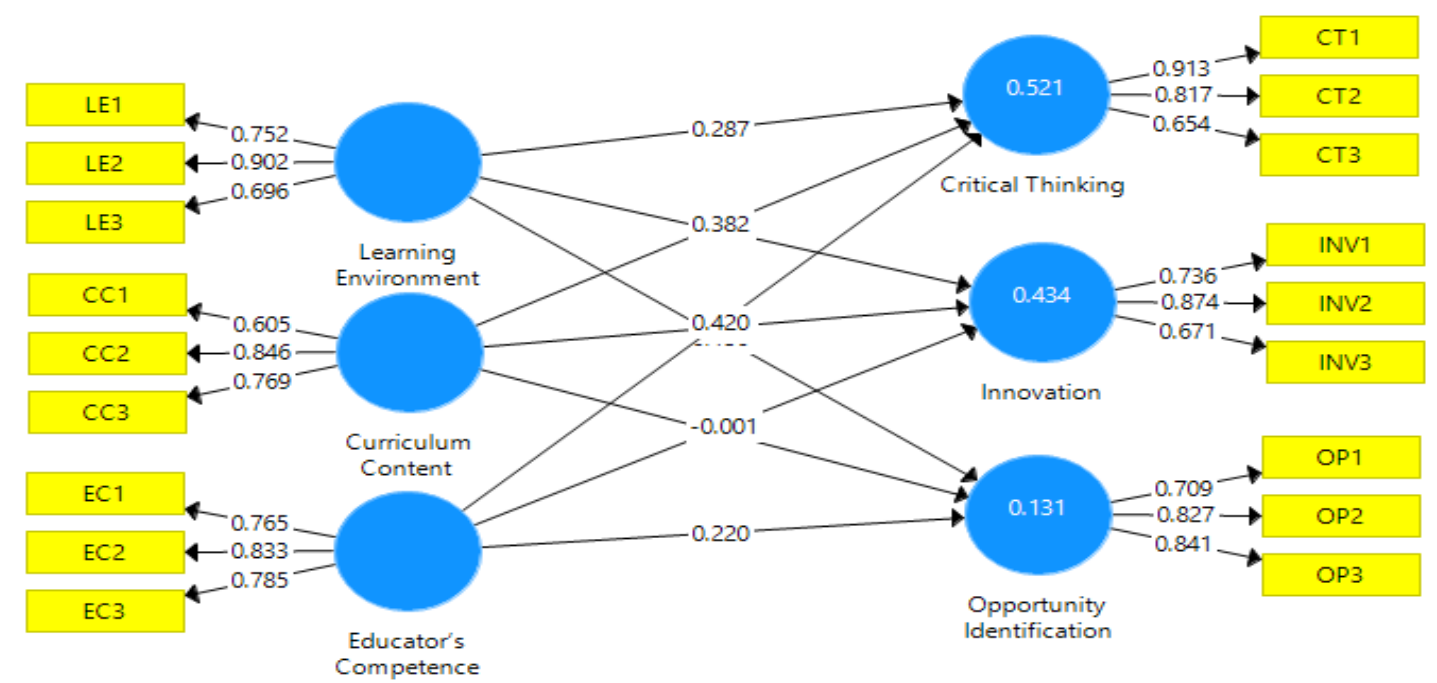

Table 4. Convergence Validity

Figure 2. Path Model and Algorithm

\begin{tabular}{ccccc}
\hline Construct & $\begin{array}{c}\text { Cronbach's } \\
\text { Alpha }\end{array}$ & rho_A & $\begin{array}{c}\text { Composite } \\
\text { Reliability }\end{array}$ & $\begin{array}{c}\text { Average } \\
\text { Variance } \\
\text { Extracted (AVE) }\end{array}$ \\
\hline $\begin{array}{c}\text { Critical Thinking } \\
\text { Curriculum } \\
\text { Content }\end{array}$ & 0.733 & 0.866 & 0.841 & 0.643 \\
$\begin{array}{c}\text { Educator's } \\
\text { Competence }\end{array}$ & 0.604 & 0.654 & 0.788 & 0.558 \\
$\begin{array}{c}\text { Innovation } \\
\text { Learning }\end{array}$ & 0.643 & 0.722 & 0.837 & 0.632 \\
$\begin{array}{c}\text { Environment } \\
\text { Opportunity }\end{array}$ & 0.708 & 0.681 & 0.807 & 0.586 \\
Identification & 0.753 & 0.845 & 0.830 & 0.621 \\
\hline
\end{tabular}

As shown in Table 4, to access the convergent validity, analysis of the factors loading, of Composite reliability (CR), and the average variance extracted (AVE) were simultaneously used. All the factors loading have a The AVE is from 0.5 to 0.6 which indicate full degree of construct validity of the criteria is accepted and used. The convergent validity indicates that all factors loading were significant at 0.01 .

\section{Discriminant Validity}

To support the construct validity of the outer model, it was essential to establish the discriminant validity.

\section{Discriminant Validity Matrix}


Table 5. Fornell-Larcker Criterion

\begin{tabular}{lcccccc}
\hline Construct & $\begin{array}{c}\text { Critical } \\
\text { Thinking }\end{array}$ & $\begin{array}{c}\text { Curriculum } \\
\text { Content }\end{array}$ & $\begin{array}{c}\text { Educator's } \\
\text { Competence }\end{array}$ & Innovation & $\begin{array}{c}\text { Learning } \\
\text { Environment }\end{array}$ & $\begin{array}{c}\text { Opportunity } \\
\text { Identification }\end{array}$ \\
\hline $\begin{array}{l}\text { Critical } \\
\text { Thinking }\end{array}$ & 0.802 & & & & & \\
$\begin{array}{l}\text { Curriculum } \\
\text { Content }\end{array}$ & 0.425 & 0.747 & & & \\
$\begin{array}{l}\text { Educator's } \\
\text { Competence }\end{array}$ & 0.597 & 0.204 & 0.795 & & \\
$\begin{array}{l}\text { Innovation } \\
\text { Learning }\end{array}$ & 0.494 & 0.658 & 0.145 & 0.765 & & \\
$\begin{array}{l}\text { Environment } \\
\text { Opportunity }\end{array}$ & 0.377 & -0.146 & 0.348 & -0.067 & 0.788 & \\
Identification & 0.507 & 0.196 & 0.307 & 0.317 & 0.201 & 0.794 \\
\hline
\end{tabular}

Table 6. The coefficient of determination

\begin{tabular}{lll}
\hline Coefficient of determination & R Square & R Square Adjusted \\
\hline Critical Thinking & 0.521 & 0.470 \\
Innovation & 0.434 & 0.373 \\
Opportunity Identification & 0.131 & 0.038
\end{tabular}

The coefficient of determination results reflects that our $\mathrm{R}^{2}$ is moderate for critical thinking and Innovation why it is weak for opportunity identification in the usefulness of a regression model as shown in Table 6 and Figure 2

Entrepreneurial venture intention is a formative construct in the PLS path model and it is assessed for validity for Collinearity issue and significance and relevance of indicators (by checking outer weights and outer loadings).

Table 7.

\begin{tabular}{lc}
\hline Collinearity Statistics (VIF) & Outer VIF Values \\
\hline & VIF \\
CC1 & 1.119 \\
CC2 & 1.302 \\
CC3 & 1.300 \\
CT1 & 1.670 \\
CT2 & 1.557 \\
CT3 & 1.306 \\
EC1 & 1.598 \\
EC2 & 1.731 \\
EC3 & 1.231 \\
INV1 & 1.512 \\
INV2 & 1.624 \\
INV3 & 1.125 \\
LE1 & 1.447 \\
LE2 & 1.496 \\
LE3 & 1.283 \\
OP1 & 2.320 \\
OP2 & 2.410 \\
OP3 & 1.202 \\
\hline
\end{tabular}


Collinearity Issue: All indicators of have a VIF value $<5$ as shown in Table 4.7. Hence, there is no collinearity issue present between the indicators.

Assessing the relevance and significance of the structural model relationships

Table 8. Relevance and Significance of Path Co-efficient

\begin{tabular}{lccccc}
\hline \multicolumn{1}{c}{ Variables } & $\begin{array}{c}\text { Original } \\
\text { Sample (O) }\end{array}$ & $\begin{array}{c}\text { Sample } \\
\text { Mean } \\
(\mathbf{M})\end{array}$ & $\begin{array}{c}\text { Standard } \\
\text { Deviation } \\
(\text { STDEV })\end{array}$ & $\begin{array}{c}\text { T Statistics } \\
(\mid \mathbf{O} / \text { STDEV } \mid)\end{array}$ & $\begin{array}{c}\text { P } \\
\text { Values }\end{array}$ \\
\hline $\begin{array}{l}\text { Curriculum Content -> } \\
\text { Critical Thinking }\end{array}$ & 0.382 & 0.354 & 0.147 & 2.590 & $\mathbf{0 . 0 1 0}$ \\
$\begin{array}{l}\text { Curriculum Content -> } \\
\text { Innovation }\end{array}$ & 0.663 & 0.648 & 0.160 & 4.132 & $\mathbf{0 . 0 0 0}$ \\
$\begin{array}{l}\text { Curriculum Content -> } \\
\text { Opportunity Identification }\end{array}$ & 0.173 & 0.216 & 0.223 & 0.775 & $\mathbf{0 . 4 3 9}$ \\
$\begin{array}{l}\text { Educator's Competence -> } \\
\text { Critical Thinking }\end{array}$ & 0.420 & 0.437 & 0.156 & 2.683 & $\mathbf{0 . 0 0 8}$ \\
$\begin{array}{l}\text { Educator's Competence -> } \\
\text { Innovation }\end{array}$ & -0.001 & 0.006 & 0.181 & 0.004 & $\mathbf{0 . 9 9 7}$ \\
$\begin{array}{l}\text { Educator's Competence -> } \\
\text { Opportunity Identification }\end{array}$ & 0.220 & 0.134 & 0.309 & 0.710 & $\mathbf{0 . 4 7 8}$ \\
$\begin{array}{l}\text { Learning Environment -> } \\
\text { Critical Thinking }\end{array}$ & 0.287 & 0.265 & 0.157 & 1.829 & $\mathbf{0 . 0 6 8}$ \\
$\begin{array}{l}\text { Learning Environment -> } \\
\text { Innovation }\end{array}$ & 0.030 & 0.029 & 0.220 & 0.137 & $\mathbf{0 . 8 9 1}$ \\
$\begin{array}{l}\text { Learning Environment -> } \\
\text { Opportunity Identification }\end{array}$ & 0.150 & 0.115 & 0.303 & 0.494 & $\mathbf{0 . 6 2 2}$ \\
\hline p $<0.001 ; * *$ : $p<0.01 ; *$; $<0.05$. & & & & & \\
\hline
\end{tabular}

Table 8, denote the strength of the relationships amongst all variables of Entrepreneurial Education (Curriculum content, Educator's competence and learning environment) and venture intention (Critical thinking, opportunity identification and innovation), and to verify whether these relationships among them.

\section{Path Coefficient Model}

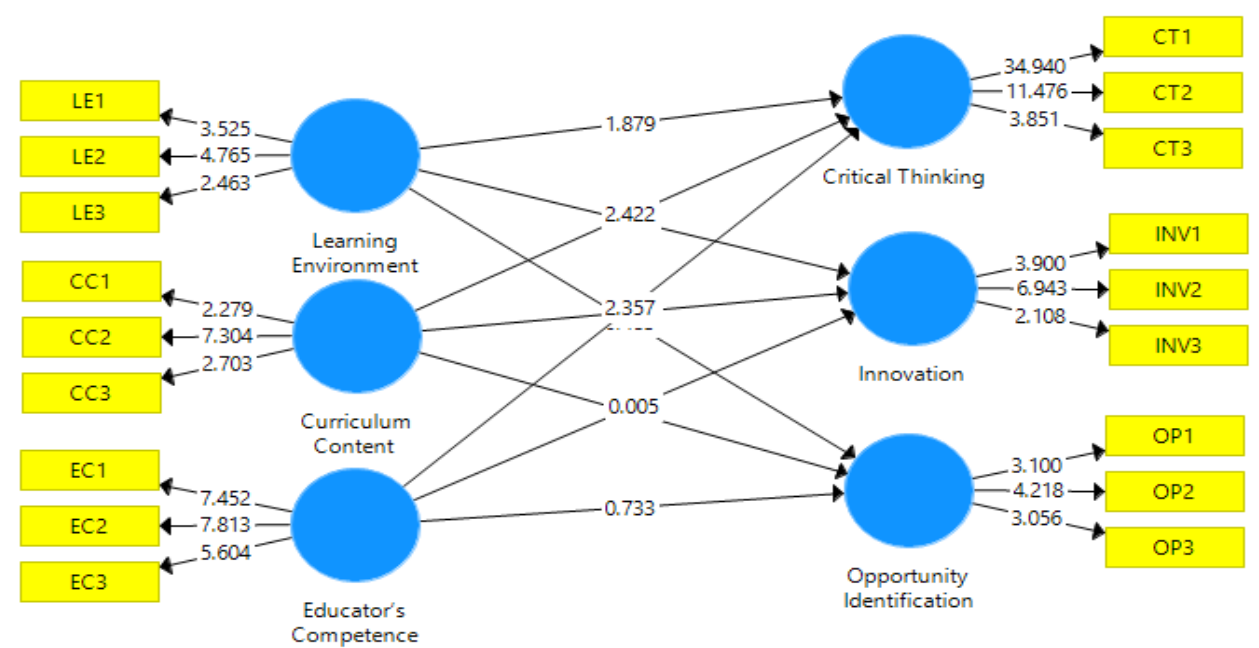

Figure 3. 
Figure 3 indicated that curriculum content and critical thinking, $(\beta=0.382, t=2.59, p>0.01)$. Curriculum Content and Innovation, $(\beta=0.663, \mathrm{t}=4.132, \mathrm{p}>0.000)$. Educator's Competence and Critical Thinking, $(\beta=0.420, \mathrm{t}=2.683$, $\mathrm{p}>0.008$ ) well-related show paths are related.

The results, on the other hand, show that Curriculum Content and Opportunity identification, $(\beta=0.173, t=0.775$, $\mathrm{p}>0.439)$ Educator's Competence and Innovation, $(\beta=-0.001, \mathrm{t}=0.004, \mathrm{p}>0.997)$ Educator's Competence and Opportunity Identification, $(\beta=0.220, \mathrm{t}=0.710, \mathrm{p}>0.478)$ Learning Environment and Critical Thinking, $(\beta=0.287$, $\mathrm{t}=1.829, \mathrm{p}>0.068)$, Learning Environment and Innovation, $(\beta=0.030, \mathrm{t}=0.137, \mathrm{p}>0.891)$ and Learning Environment and Opportunity Identification $(\beta=0.150, \mathrm{t}=0.494, \mathrm{p}>0.622)$, are not well related.

\section{Discussion}

The result revealed that the curriculum for entrepreneurship programmes stimulate and enables students to think critically by developing novel business ideas. However, the practical aspect of the entrepreneurship education is weak. This is validated by the studies of (Unger \& Crawford,1992), who revealed lack of understanding of entrepreneurship education as a major barrier affecting the effective delivery of entrepreneurship education in Tertiary Institutions. This is also supported by the findings of (Römer-Paakkanen \& Pekkala, 2008; Ogbari et al, 2018), which stated that students who are interested in launching a business, should be encouraged to do so.

Another finding indicated that the use of effective pedagogy in entrepreneurship accelerate the evolution of business start-ups, by inspiring students' interest through teaching practices that are action-based. But, the absence of the combination of theoretical and practical approaches may frustrate the expression of enterprise potentials by female engineering students. This is corroborated with the finding of (Keat, Selvarajah, \& Meyer, 2011), which shows that class activities dominated by theory is demotivating and diminishes interest and focus. This is also supported by the postulation of (Olokundun, et al., 2017; Moses \& Amalu, 2010; Badri and Hachicha, 2019), which shows that the absence of the right blend of theoretical and practical experience in the classroom that does not offer real-world experience to students make learning a boring experience.

The study suggested that entrepreneurial competencies of educators stimulate students to develop the intention to launch a business in their field of study upon graduation. However, some of the educators are inadequately equipped with cutting edge knowledge to deliver entrepreneurship courses effectively. This is in line with the study of Ibidunni,et al., (2017), who advanced that there is a scarcity of educators with entrepreneurial competence. This suggests those who are teaching entrepreneurship classes need relevant training to acquire skills and experience to deliver core entrepreneurship courses.

\section{Conclusion}

This study indicates that the curriculum contents for entrepreneurship programmes stimulate students to think critically by developing novel business ideas. However, the practical aspect of entrepreneurship education is weak, while the emphasis is placed on the acquisition of vocational skills as against the development of entrepreneurial competencies.

Also, valid evidence indicates that the employment of effective pedagogy in entrepreneurship accelerates the evolution of business start-ups, by inspiring students' interest through teaching practices that are action-based. But, the absence of the combination theoretical and practical approach may frustrate the expression of enterprise potentials by female engineering students.

Besides, there are abundant evidences to suggest that the entrepreneurial competencies of educators stimulate students to develop the intention to launch a business in their field of study upon graduation. However, some of the educators need to be empowered through training on the used cutting edge approaches to deliver entrepreneurship courses effectively.

Another valid inference evident in this study is that the university's' learning environment offers experiences such as entrepreneurship mentoring and seed funding, which is considered suitable for innovations. However, these supports need to be introduced early enough to boost entrepreneurial activities.

\section{Recommendations and Policy Implication}

I. One major recommendation is that the entrepreneurship curriculum should extensively put emphasis on social entrepreneurship, critical thinking focusing on the societal benefits of cultivating innovative and entrepreneurial solutions. Participation by students during business idea generation exercises should be intentional and accorded major priority. Also, female engineering must be encouraged to be collaborating with other women. This is important 
because being part of networks and communicating with others is relevant to helping women develop the confidence to start their own business.

II. The engagement of guest speakers, individual and group project with entrepreneurial competences, is very germane to stimulating students' interest in launching start-ups.

III. Policymakers should partner with training institutions and ensure that entrepreneurship educators are adequately trained to develop the relevant enterprise skill that will inspire commitment from students to value, embrace business plan writing, and development of business canvas. Business plan writing and development of business canvas should be considered a requirement for graduation. This idea is predicated on the fact many investors and other stakeholder support systems are favorable dispose to business plan competitions as a basis to provide financial support to start-ups.

\section{Significance of Statement}

This study discovers that practical approach to entrepreneurship education with a specific focus on students' field of study thus, creating an enthusiasm in them to apply such skills on graduation. Therefore, the result will be beneficial to managements in higher institutions to formulate and implement policies that will encourage female engineering undergraduates' engagement in innovative ventures as well as entrepreneurial development in Nigerian higher institutions.

The study also indicates that the engagement of guest speakers, individual and group projects with entrepreneurial competencies, is very germane to stimulating the development of female entrepreneurial skills. This will support the review of the policy that will inspire the propensity of students to create jobs and to reduce unemployment among them.

Also, this study will add to the existing body of knowledge in entrepreneurship education, by developing a venture intention model which will be helpful for researchers in undertaking further research in other related areas of study.

\section{Acknowledgment}

The researchers appreciate the support of Landmark University for sponsoring this research.

\section{References}

Adeyeye, M. M. (2017). Market innovation for economic diversification in Lagos: A resource-based perspective. Ghanaian Journal of Economics, 5(1), 96-116.

Ahmed, T., Chandran, V. G. R., Klobas J. E., Linan F., \& Kokkalis P. (2020). Entrepreneurship education programmes: How learning, inspiration and resources affect intention for new venture creation in a developing economy. The International Journal of Management Education, 18. https://doi.org/10.1016/j.ijme.2019.100327

Ahmad, S. Z. (2011). Evidence of the characteristics of women entrepreneurs in the Kingdom of Saudi Arabia. International journal of gender and entrepreneurship.

Badri \& Hachicha, (2019). Entrepreneurship education and its impact on students' intention to start up: A sample case of students from two Tunisian universities. International Journal of Management Education, 17, 182-190. https://doi.org/10.1016/j.ijme.2019.02.004

Buttner, E. H. (1993). Female entrepreneurs: how far have they come? BUSINESS HORIZONS-BLOOMINGTON, 36, 59-59. http://citeseerx.ist.psu.edu/viewdoc/download?doi=10.1.1.424.1495\&rep=rep1\&type=pdf

DeMartino, R., \& Barbato, R. (2003). Differences between women and men MBA entrepreneurs: exploring family flexibility and wealth creation as career motivators. Journal of business venturing, 18(6), 815-832. https://doi.org/10.1016/S0883-9026(03)00003-X

Dou X., Zhu X., Zhang J. Q., \& Wang J., (2019) Outcomes of entrepreneurship education in China: A customer experience management perspective. Journal of Business Research, 103, 338-347. https://doi.org/10.1016/j.jbusres.2019.01.058

Gabadeen, W. O., \& Raimi, L. (2012). Management of entrepreneurship education in Nigerian higher institutions: Issues, challenges and way forward. Abuja International Journal of Education And Management Sciences (ABIJEMS), 2, https://www.researchgate.net/profile/Lukman_Raimi2/publication/291043294_Management_of_Entrepreneursh ip_Education_in_Nigerian_Higher_Institutions_Issues_Challenges_and_Way_Forward/links/569e93ae08ae21a 56424c94b.pdf 
Goby, V. P., \& Erogul, M. S. (2011,). Female entrepreneurship in the United Arab Emirates: Legislative encouragements and cultural constraints. In Women's Studies International Forum (Vol. 34, No. 4, pp. 329-334). Pergamon. https://doi.org/10.1016/j.wsif.2011.04.006

Ibidunni, A. S., Peter, F., \& Ogbari, M. (2017). Entrepreneurship educator's competence on university students' commitment to learning and business plan writing. Academy of Strategic Management Journal, 16(2), 1-10. http://eprints.covenantu niversity.edu.ng/id/eprint/9671

Ibidunni, A. S., Ibidunni, O. M., Olokundun, A. M., Oke, O. A., Ayeni, A. W., Falola, H. O., ... \& Borishade, T. T. (2018). Examining the moderating effect of entrepreneurs' demographic characteristics on strategic entrepreneurial orientations and competitiveness of SMEs. Journal of Entrepreneurship Education, 21(1).

Igwe, P. A., Okolie, U. C., \& Nwokoro, C. V. (2019). Towards a responsible entrepreneurship education and the future of the workplace. The International Journal of Management Education. https://doi.org/10.1016/j.ijme.2019.05.001

Ismail, K., Anuar, M. A., Omar, W. W., Aziz, A. A., Seohod, K., \& Akhtar, C. S. (2015). Entrepreneurial intention, entrepreneurial orientation of faculty and students towards commercialization. Procedia-Social and Behavioral Sciences, 181, 349-355. https://doi.org/10.1016/j.sbspro.2015.04.897

Jamali, D. (2009). Constraints and opportunities facing women entrepreneurs in developing countries: A relational perspective. Gender in management: an international journal, 24(4), 232-251. https://doi.org/10.1108/17542410910961532

Jannoo, Z., Yap, B. W., Auchoybur, N., \& Lazim, M. A. (2014). The effect of nonnormality on CB-SEM and PLS-SEM path estimates. International Journal of Mathematical, Computational, Physical and Quantum Engineering, 8(2), 285-291.

Jena, R. K (2020). Measuring the impact of business management student's attitude towards entrepreneurship education on entrepreneurial intention: A case study. Computers in Human Behavior, 107. https://doi.org/10.1016/j.chb.2020.106275

João Almeida, Ana Dias Daniel and Cláudia Figueiredo (2019). The future of management education: The role of entrepreneurship education and junior enterprises. The International Journal of Management Education. https://doi.org/10.1016/j.ijme.2019.100318

Keat, O. Y., Selvarajah, C., \& Meyer, D. (2011). Inclination towards entrepreneurship among university students: An empirical study of Malaysian university students. International Journal of Business and Social Science, 2(4). www.ijbssnet.com

Lerner, M., Brush, C., \& Hisrich, R. (1997). Israeli women entrepreneurs: An examination of factors affecting performance. Journal of business venturing, 12(4), 315-339. https://doi.org/10.1016/S0883-9026(96)00061-4

Marlow, S., \& Martinez Dy, A. (2018). Annual review article: Is it time to rethink the gender agenda in entrepreneurship research? International Small Business Journal, 36(1), https://doi.org/10.1177\%2F0266242617738321

McMullen, J. S., \& Warnick, B. J. (2016). Should we require every new venture to be a hybrid organization? Journal of Management Studies, 53(4), 630-662. https://doi.org/10.1111/joms.12150

Moses, C., \& Amalu, R. (2010). Entrepreneurial motivations as determinants of women entrepreneurship challenges. Petroleum-Gas University of Ploiesti Bulletin, (2), 67-77.

Mwobobia, F. M. (2012). The Challenges Facing Small- Scale Women Entrepreneurs: A case of Kenya. International Journal of Business Administration, 3(2). https://doi.org/10.5430/ijba.v3n2p112

Ogbari, Olokundun, Uzuegbunam, Isiavwe, Ilogho, Obi and Moses (2018). Data on Entrepreneurship Education and Entrepreneurial performance of aspiring entrepreneurs in selected Nigerian universities. Elsevier Inc. Data in brief, 20, 108-112. https://doi.org/10.1016/j.dib.2018.07.044

Oguntimehin, Y. A. (2018). The relationship between entrepreneurship education and students' entrepreneurial intentions in Ogun state-owned universities, Nigeria. KIU Journal of Humanities, 3(2), 285-294.

Olokundun, A. M., Ibidunni, A. S., Peter, F., Amaihian, A. B., Moses, C., \& Iyiola, O. O. (2017). Experiential pedagogy and shared vision: a focus on identification of business opportunities by Nigerian University 
Students. Journal of $\quad$ Entrepreneurship $\quad$ Education, 20(2), 1-12. http://eprints.covenantuniversity.edu.ng/id/eprint/1674

Onuma, N. (2016). Entrepreneurship education in Nigerian tertiary institutions: A remedy to graduates unemployment. British Journal of Education, 4(5), 16-28. www.eajournals.org

Orhan, M., \& Scott, D. (2001). Why women enter into entrepreneurship: an explanatory model. Women in management review. https://doi.org/10.1108/09649420110395719

Orhan, M. (2001). Women business owners in France: the issue of financing discrimination. Journal of Small Business Management, 39(1), 95. https://doi.org/10.1111/0447-2778.00009

Parker, S. C. (2018). The economics of entrepreneurship. Cambridge University Press. https://doi.org/10.1017/9781316756706

Römer-Paakkanen, T., \& Pekkala, A. (2008). Generating entrepreneurship and new learning environments from student's free-time activities and hobbies. Liiketaloudellinen aikakauskirja, 3(2008), 341-361.

Raimi, L., Akhuemonkhan, I., \& Ogunjirin, O. D. (2015). Corporate Social Responsibility and Entrepreneurship (CSRE): antidotes to poverty, insecurity and underdevelopment in Nigeria. Social Responsibility Journal. https://doi.org/10.1108/SRJ-11-2012-0138

Ronstadt, R., \& Robert, R. (1984). Entrepreneurship: Text, cases and notes. Lord Pub.

Shane, S., \& Venkataraman, S. (2001). Entrepreneurship as a field of research: A response to Zahra and Dess, Singh, and Erikson. Academy of management review, 26(1), 13-16. https://doi.org/10.5465/amr.2001.27879269

Unger, R. K., \& Crawford, M. E. (1992). Women and gender: A feminist psychology. Temple University Press. https://psycnet.apa.org/record/1992-97152-000

Yahaya, U. (2011). Overview of entrepreneurship education in Nigeria Universities. National University Commission, Abuja.

Zahra, S. A., \& Wright, M. (2016). Understanding the social role of entrepreneurship. Journal of Management Studies, 53(4), 610-629. https://doi.org/10.1111/joms.12149

\section{Copyrights}

Copyright for this article is retained by the author(s), with first publication rights granted to the journal.

This is an open-access article distributed under the terms and conditions of the Creative Commons Attribution license (http://creativecommons.org/licenses/by/4.0/). 